Archaeological Journal

\title{
A Newly Discovered English Mediaeval Chalice and Paten
}

\section{H. P. Mitchell}

To cite this article: H. P. Mitchell (1904) A Newly Discovered English Mediaeval Chalice and Paten, Archaeological Journal, 61:1, 181-184, DOI: 10.1080/00665983.1904.10852968

To link to this article: http://dx.doi.org/10.1080/00665983.1904.10852968

曲 Published online: 17 Jul 2014.

Submit your article to this journal $\asymp$

Џ Article views: 2

Q View related articles $\sqsubset$ 


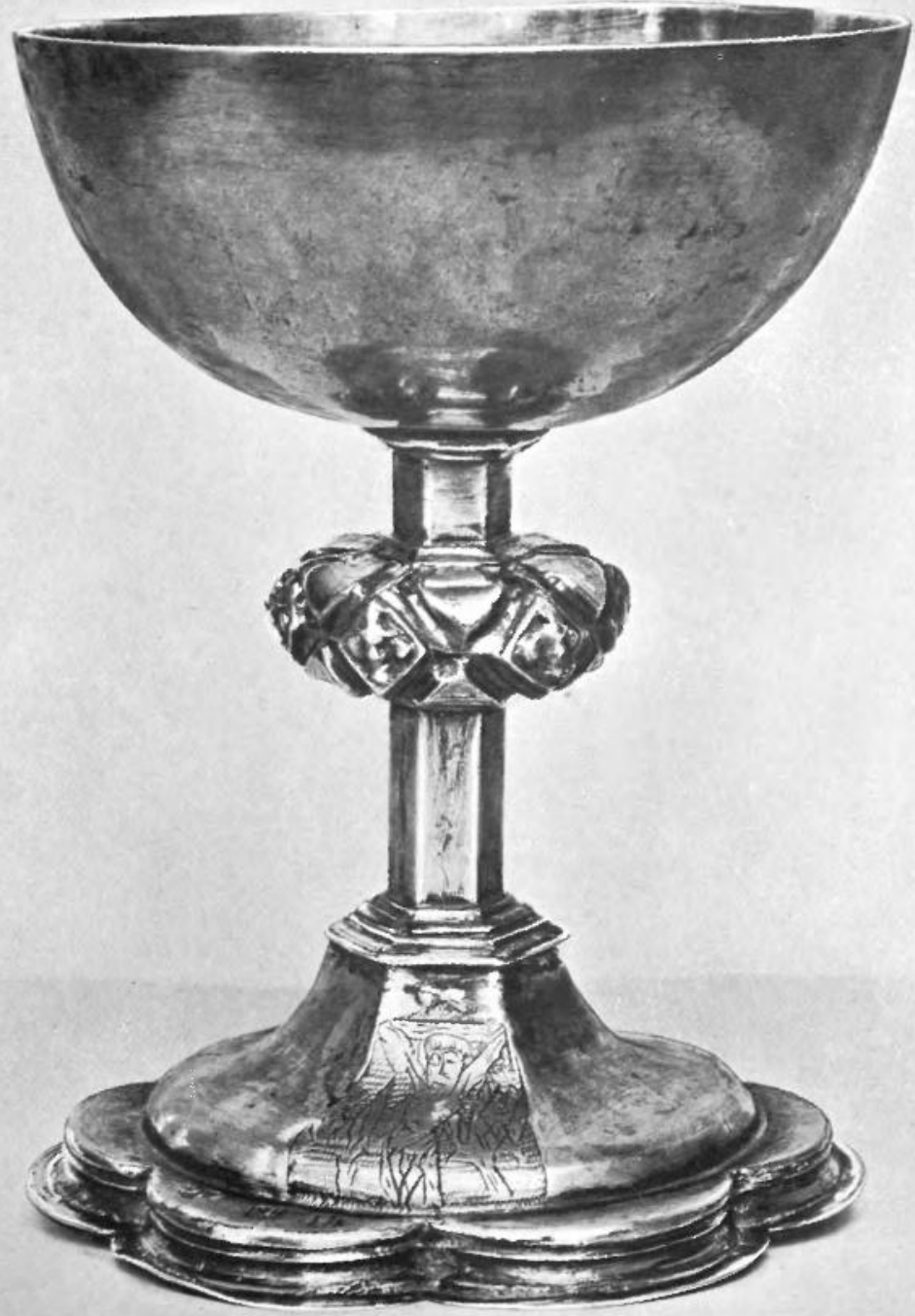




\section{A NEWLY DISCOVERED ENGLISH MEDIAEVAL CHALICE AND PATEN. ${ }^{1}$}

By H. P. MI'TCHELL.

The chalice shown in the photograph forms one more addition to the scanty number of examples still existing, made in this country before the final breaking a way from the traditions of the mediaeval church. It is accompanied by its paten, and both pieces are in an honest state of repair, somewhat scratched and battered with nearly four centuries of wear and tear, but free from any tinkering more serious than the re-soldering of the stem of the chalice. They have lately been added to the national collection of silversmiths' work at South Kensington, and their history lends some special interest to the acquisition. It may be surmised that, at the time of the general destruction of church plate under Henry VIII., Edward VI., and Elizabeth, they were alienated from the church they had served, and fortunately for a later age, were conveyed abroad instead of being cast into the melting-pot. What were the circumstances which carried them so far as Iceland imagination alone can suggest. All that can be said is that there were considerable trade relations between this country and Iceland in the sixteenth century, and that it is fiom the village of Eyrarbakki, on the south coast of that remote island, that these specimens have been brought home, through the agency of a continental dealer, to the country of their origin.

The chalice is of the general form classified as type $G$ in the treatise on the subject contributed by Messrs. St. John Hope and Fallow to volume XLIII of this Journal, in which the characteristic feature of a sexfoil foot is first introduced, a design of great practical convenience. Four examples of the type are quoted by 
the authors referred to, and to those are to be added one since discovered at Ebbesbourne, Wilts, ${ }^{1}$ a sixth in private possession, ${ }^{-}$and the one now published. Of these, three are dated by their marks as of the years 1507-8, 1518$19,^{3}$ and 1521-2. The example now under notice and its paten are both well marked with the leopard's head crowned, the London date-letter $\mathrm{K}$ for $1527-8,{ }^{4}$ and maker's mark a $\mathrm{T}$ charged with three pellets. This carries the type $G$ six years later than heretofore, into the period of the next and last type of pre-Reformation chalice designated $\mathrm{H}$.

As will be seen from the photograph, the foot of the chalice consists of a pedestal, hexagonal above and circular below, of ogee profile, rising from a sexfoil plinth with vertical moulded edge, flanged below. The six-sided stem is unequally divided by the knop, the junctions being marked by plainly moulded bands. The knop is rather flat in shape, its surface unpierced but divided by grooves into pointed panels above and below and six lozenge-shaped bosses round the circumference, the former plain, the latter embossed each with a rude representation of the face of an angel. The bowl is plain, and of the nearly hemispherical shape which has been remarked at this period by another authority. ${ }^{5}$

The spread of the foot bears the Crucifixion, engraved in an extremely rough manner, the ground matted with parallel zigzags in a way characteristic of English work of the time. At either side of the cross is a plant, as in many other instances, each in this case bearing a cone or flower. It has been suggested that these plants represent particular species ${ }^{\circ}$ it may be safely assumed at any rate that they have a symbolical meaning. Possibly they stand for the roses and daisies of the

${ }^{1}$ Nightingale, J. E., The Church Plate of the County of Wilts, 1891, p. $5 \mathrm{l}$.

- Burlington Fine Arts Club. Exhibition of European Silrersmiths' Work, 1901. Illustrated Catalogue, Pl. XXII. (This plate also shows Lord Hatherton's chalice from Pillaton Hall.) 18.

3 Formerly believed to be of $1517-$

it The date-letter is remarkably clear on the paten, and it will be noticed that it does not show the deep notches at the ends of the limbs which hare been attributed to the letter for this year, perhaps on insufficient eridence.

s Cripps, $1 \%$. J.. Old Enqlish Plate, 8th ed, pp. 219, 230. The chalices at Ebbesbourne (as figured, though not as described), at 'Trinity College, Oxford, and in Mr. C. J. Jackson's collection, offer examples approaching this shape.

${ }^{6}$ See the article referred $t c$, Vol. XLIII, p. $1+8$. 
mediaeval Calvary scenes, symbolizing the passion and resurrection of Christ. ${ }^{1}$ Almost equally appropriate would be the myrrh and aloes of the burial : or again we may see in them the tree of kmowledge and the tree of life.

The paten has a sexfoil depression, with the face of Christ or vernicle in the middle and foliage in the spandrels. It is of the type $\mathrm{D}$ in the classification already quoted, of which as many as forty-nine examples were described as then known (1886), and to this number at least half a dozen have since been added. The present specimen is peculiar in having the boldly sunk sexfoil combined with a slight circular concavity, instead of being set well within it. The edge is bordered with two lines and a slight hollow moulding. The engraving is of the coarsest description, the ground of the subject matted as on the chalice. The centres from which the main circles and the lobes of the sexfoil are struck are distinctly marked, the principal one indeed disfigures in a most unfortunate manner the almost grotesque representation of the face.

Gilding by the old mercury process is applied to the chalice on the knop, the edge and flange of the foot, the moulding at its top, and the engraved subject, and to the paten on the central subject, the spandrels, and the moulded edge. The measurements are: chalice, height $5 \frac{1}{16}$ inches, diameter (both bowl and foot) $3 \frac{11}{16}$ inches; paten, diameter $4 \frac{1}{8}$ inches.

The deplorably debased character of the whole of the engraved ornament which has been described, equalled in rudeness by several contemporary examples, stands as evidence of a period of great decline in artistic power. Yet the charming proportions and graceful design of both chalice and paten show how noble was still the main inspiration of mediaeval art in this country, even at the close of its career and when about to pass away with the traditions of the church in whose service it had sprung to life and flourished.

1 See Barbier de Montault, X, Icono. graphie Chretienne, II, 156.
- The photograph reduces the apparent width of the foot as compared with the bowl. 


\section{Supplementary Note on the Classification of Tudor Chalices.}

Since the appearance of the classification published in volume XLIII of this Journal, no less than five examples of the last two types of English mediaeval chalice have been discovered. A design of which only one example was formerly known is now represented by three, and sufficient material having been thus provided, it might be an advantage to take account of this variety in the classification. By subdividing Messrs. Hope and Fallow's last class into two (a plan adopted for some of the earlier types) due prominence is given to the shape of the foot, the most salient feature of distinction.

The following list represents the result of such an arrangement ${ }^{1}$ :-

TrPe G. Sexfoil foot with plain mouldings at junction with stem. Bowl plain; changing from conical to hemispherical, or wide and shallow. Knop with six lozenge-shaped bosses bearing flowers or angelmasks.

$\begin{array}{lllll}\text { Corpus Christi College, Oxford } & \ldots & \ldots & 1507-8 \\ \text { Leyland, Lancs. ... } & \ldots & \ldots & \ldots & 1518-19 \\ \text { St. Sampson, -Guernsey } & \ldots & \ldots & \ldots & \text { c. 1520 } \\ \text { Jurby, Isle of Man } & \ldots & \ldots & \ldots & 1521-2 \\ \text { Mr. C. J. Jackson } & \ldots & \ldots & \ldots & \text { c. 1520-5 } \\ \text { Ebbbesbourne, Wilts } & \ldots & \ldots & \ldots & \text { c. 1520-5 } \\ \text { Victoria and Albert Museum } & \ldots & \ldots & 1527-8\end{array}$

Type H. Foot with parapet or cresting at the top. Bowl inscribed, usually wide and shallow. Knop as before, but generally flatter. Stem corded at angles.

a. Flowing foot.

$\begin{array}{llllll}\text { Wylye, Wilts } & \ldots & \ldots & \ldots & \ldots & 1525-6\end{array}$

Trinity College, Oxford $\ldots . \quad \ldots \quad \ldots \quad \ldots \quad 1527-8$

b. Sexfoil foot.

Pillaton Hall (stem buttressed at angles) c. 1530-5

Highworth, Wilts $\quad \ldots \quad \ldots \quad \ldots \quad 1534-5$

Sturminster Marshall, Dorset (bowl plain; knop lost and stem altered) $\quad \ldots \quad \ldots \quad 1536-7$

The flowing foot of Type $\mathrm{H} a$. was perhaps borrowed from the Spanish chalices in florid late Gothic taste, in which it is a common feature. A princess of Spain was at this time queen of Henry VIII.; a lively imagination will not fail to observe that no example of the Peninsular type of foot is known after the year 1527, in which Henry's intention of obtaining a divorce from Katharine of Aragon became public. It is more to the point to remark that the sexfoil foot was a more convenient shape for reasons suggested by the authors already referred to.

The Pillaton Hall chalice was formerly assigned a date c. 1525. It now seems more natural to take as a guide the date of those it most closely resembles.

1 For descriptions see previous re. ferences, and also J. E. Nightingale,

Church Plate of the Counly of Dorset, 1889. 


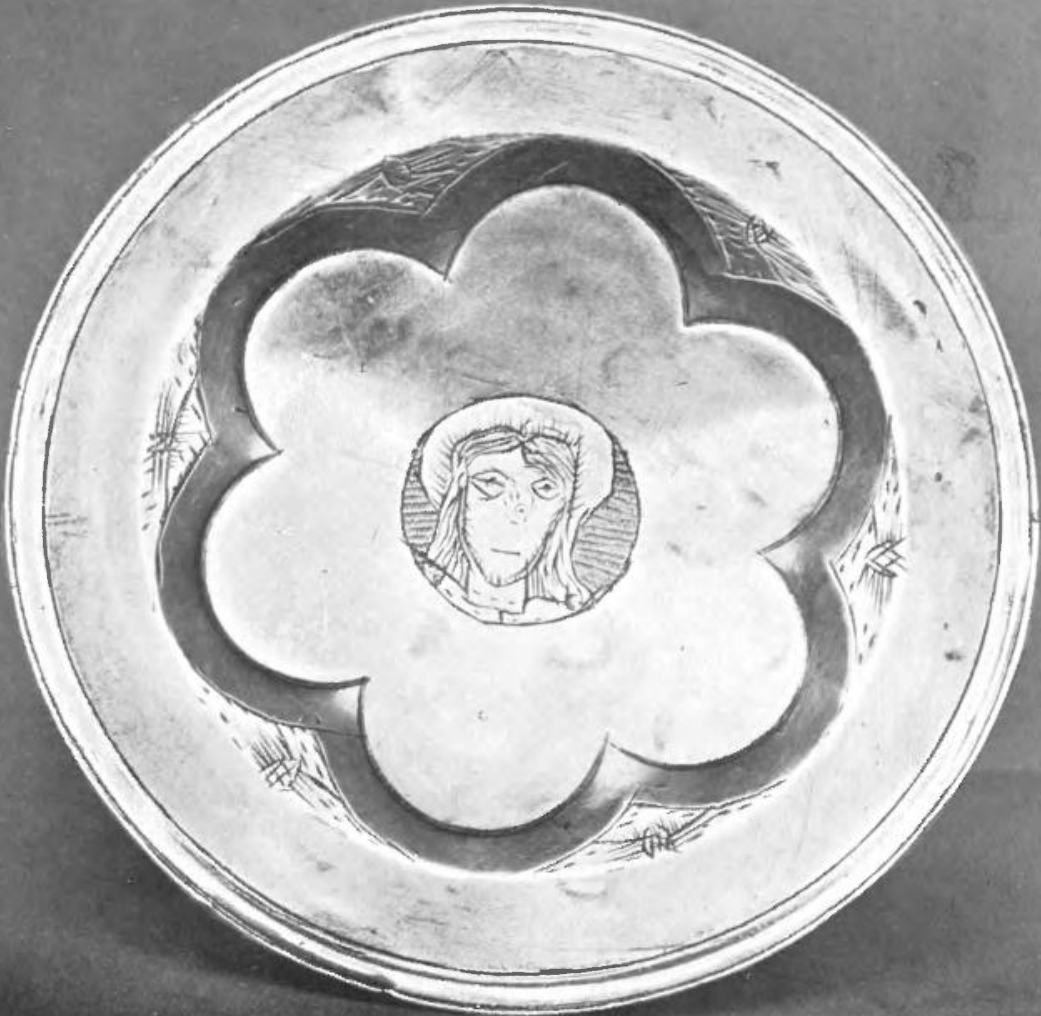

PATEN BELONGING TO THE CHALICE.
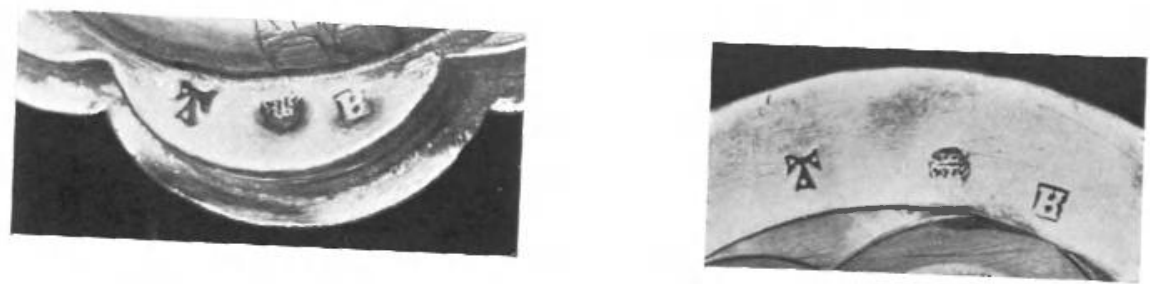

MARKS ON CHALICE, 